\title{
Integracja europejska a redefinicja polityki zagranicznej Stanów Zjednoczonych: przyczyny zainicjowania i rozwój transatlantyckich stosunków bezpieczeństwa w latach 1945-1948
}

\begin{abstract}
Wstęp
Wraz z końcem drugiej wojny światowej nastąiły fundamentalne przeobrażenia na kontynencie europejskim. Po pierwsze, Europa w sposób niezwykle wyraźny zaczęła tracić na znaczeniu w polityce międzynarodowej, przestając być arbitrem, który przez wieki decydował o losach świata. Po drugie, Europa stała się przedmiotem rywalizacji Wschód-Zachód. O losach Europy w większej mierze zaczęły decydować dwa nowe supermocarstwa, tj. Stany Zjednoczone i Związek Radziecki, niż sami Europejczycy. Nie oznaczało to, że państwa europejskie nie dążyły do rozwiązywania własnych problemów, ale ich możliwości z uwagi na zniszczenia wojenne były w znacznej mierze ograniczone. Państwom europejskim na własną rękę trudno było stawić czoła szeregu wyzwaniom, z których jednym z najpoważniejszych była kwestia zapewnienia bezpieczeństwa. Problem ten nie tylko był istotny z uwagi na dwie światowe i totalne wojny, które miały miejsce w pierwszej połowie XX wieku i doprowadziły do największej w dziejach ludzkości katastrofy o wielowymiarowym charakterze. Był również związany z wybuchem zimnej wojny, której skutki były trudne do przewidzenia z uwagi na rozwój broni masowego rażenia, czyli przede wszystkim atomowej, ale również wodorowej. Pomimo zakończenia działań wojennych, świat po 1945 r. wcale nie wkraczał w okres stabilizacji, pokoju i bezpieczeństwa. Identyfikowana więc była potrzeba podjęcia współpracy pomiędzy państwami europejskimi, a w jej ramach podkreślano konieczność instytucjonalizacji działań na rzecz zapewnienia bezpieczeństwa. $\mathrm{Z}$ uwagi na podział Europy na Wschód i Zachód współpraca europejska, także w szerszym transatlantyckim wymiarze, ograniczyła się do Europy Zachodniej, czyli tej części, która w sposób demokratyczny mogła podejmować decyzje o własnej przyszłości.

Już w momencie pojawienia się pierwszych prób inicjowania współpracy w zakresie polityki bezpieczeństwa i obrony tuż po drugiej wojnie światowej unaoczniły się dylematy dotyczące jej instytucjonalizacji. Pierwszym zasadniczym problemem była odpowiedź na pytanie dotyczące udziału Stanów Zjednoczonych w stworzeniu systemu, dzięki któremu można by przeciwdziałać zagrożeniom zewnętrznym. Innymi słowy rozważano przyjęcie rozwiązań o charakterze transatlantyckim, czyli z udziałem Stanów Zjednoczonych i Kanady, albo jedynie europejskich, w których współpraca czy wspólna obrona byłaby zbudowana wyłącznie przez państwa europejskie bez Amerykanów. Po drugie, z uwagi na zainicjowanie po drugiej wojnie światowej proce-
\end{abstract}


sów integracji na kontynencie europejskim, pojawił się problem, czy przyjęte rozwiązania instytucjonalne powinny być kształtowane w oparciu o model międzyrządowy, w którym nie naruszano by uprawnień poszczególnych członków, czy też o koncepcję ponadnarodową ograniczającą w jakimś zakresie suwerenność państw. Te dwa podstawowe dylematy kształtowały debatę o obronie europejskiej nie tylko po zakończeniu drugiej wojny światowej, ale miały wpływ na wysuwane koncepcje i toczone spory pomiędzy państwami europejskimi w okresach późniejszych. Powstanie Europejskiej Polityki Bezpieczeństwa i Obrony w ramach Unii Europejskiej w 1999 r., co było owocem przede wszystkim kompromisu osiagniętego pomiędzy Francją i Wielką Brytania, w pełni nie rozwiązało powyższych dylematów. Nie zmienił tego także Traktat Lizboński, który wszedł w życie 1 grudnia 2009 r. Zarówno dyskusja, jak i działania państw członkowskich Unii Europejskiej na arenie międzynarodowej, świadczą o braku wykrystalizowania się jednoznacznej koncepcji, która mogłaby przesądzać o kształcie rozwiązań w zakresie Wspólnej Polityki Bezpieczeństwa i Obrony. Określenie relacji ze Stanami Zjednoczonymi oraz pytanie o ewentualne przeniesienie części suwerennych uprawnień przez państwa na szczebel europejski - to nadal obecne problemy, bez rozstrzygnięcia których Unia Europejska nie rozwiąże problemu swojej obecności na arenie międzynarodowej w zakresie polityki bezpieczeństwa i obrony. Genezy współczesnych problemów i dylematów należy więc szukać w dyskusjach i działaniach, które miały miejsce tuż po zakończeniu drugiej wojny światowej.

Rozwój współpracy w zakresie polityki bezpieczeństwa i obrony w Europie Zachodniej tuż po drugiej wojnie światowej ukształtował fundamenty relacji transatlantyckich, których zwieńczeniem było powstanie Sojuszu Atlantyckiego (NATO) w 1949 r. Celem niniejszego artykułu jest ukazanie genezy transatlantyckich stosunków bezpieczeństwa, które po 1945 r. zaczęły się rozwijać w wyniku dwóch istotnych procesów. Po pierwsze, Stany Zjednoczone, stając się jednym z supermocarstw, dokonały bardzo istotnej redefinicji swojej polityki zagranicznej, odchodząc od polityki izolacjonizmu na rzecz zaangażowania w sprawy europejskie i globalne. Po drugie, państwa Europy Zachodniej zainicjowały działania na rzecz integracji kontynentu europejskiego w różnych obszarach, których celem było stworzenie pokojowej i bezpiecznej Europy. Dzięki aktywności Stanów Zjednoczonych, jak i reakcji państw Europy Zachodniej, określono w latach 40. XX wieku zakres transatlantyckiej umowy (transatlantic bargain), która pomimo zmian w dekadach późniejszych, w dużej mierze obowiązuje do dzisiaj.

\section{Nowy porządek w Europie po 1945 r.: w kierunku zjednoczenia}

Jednym z podstawowych zadań, przed którym stanęły państwa zwycięskiej koalicji drugiej wojny światowej było ustanowienie nowego porządku globalnego i przede wszystkim w Europie, dzięki któremu udałoby się zapewnić pokój i bezpieczeństwo. Jeszcze w trakcie działań wojennych ujawniły się poważne różnice zdań pomiędzy państwami Wielkiej Trójki (Kissinger, 1996, s. 429). Podczas gdy premier Wielkiej Brytanii Winston Churchill dążył do stworzenia systemu równowagi sił, dzięki któremu Wielka Brytania wraz ze Stanami Zjednoczonymi, a nawet Niemcami, stworzy- 
łyby przeciwwagę dla Związku Radzieckiego, to prezydent Stanów Zjednoczonych Franklin Delano Roosevelt forsował ideę „Czterech Policjantów”, czyli dyrektoriatu USA, Wielkiej Brytanii, ZSRR i Chin, które przeciwdziałałyby zagrożeniom, najprawdopodobniej ze strony Niemiec. Inną koncepcję prezentował przywódca Związku Radzieckiego Józef Stalin. Dążył on do rozszerzenia rosyjskiej strefy wpływów i stworzenia z podporządkowanych sobie państw buforu pomiędzy ZSRR a Niemcami. Odmienność prezentowanych sposobów myślenia nie dotyczyła jedynie konkretnych proponowanych rozwiązań, ale wynikała także z czerpania z innych źródeł teoretycznych dotyczących stosunków międzynarodowych. Koncepcje Churchilla i Stalina można by umieścić w ramach realistycznej wizji rzeczywistości międzynarodowej, natomiast u Roosevelta wyraźnie występują idealistyczne elementy teorii liberalnej. Spór pomiędzy realizmem a podejściem liberalnym nie był jednak istotny z punktu widzenia planowania porządku powojennego. Pomimo stworzenia Narodów Zjednoczonych jako uniwersalnej organizacji kolektywnego bezpieczeństwa, stosunki międzynarodowe po 1945 r. z uwagi na wybuch zimnej wojny rozwijały się zgodnie z paradygmatem realistycznym.

$\mathrm{Na}$ tle rosnącej rywalizacji pomiędzy Stanami Zjednoczonymi a Związkiem Radzieckim, w Europie zaczęły zachodzić procesy, które doprowadziły do istotnych zmian $\mathrm{w}$ relacjach pomiędzy demokratycznymi państwami zachodnimi. Związane były one z zainicjowaniem integracji europejskiej, dzięki której miano rozwiązać szereg wyzwań stojących przed państwami narodowymi. Dotyczyły one zarówno sfery gospodarczej, jak i problemów związanych z zapewnieniem bezpieczeństwa. Integracja pomiędzy państwami Europy Zachodniej nie mogłaby mieć miejsca bez aktywnej roli Stanów Zjednoczonych na kontynencie europejskim. Amerykanie pomogli Europejczykom zarówno w odbudowie gospodarczej po zniszczeniach wojennych, dzięki czemu mogła nastąpić stabilizacja polityczna poszczególnych państw, ale zapewnili również bezpieczeństwo dzięki powstaniu NATO. Nie oznaczało to jednak, że Europejczycy nie próbowali również stworzyć systemu przeciwdziałania zagrożeniom zewnętrznym na własną rękę, jednak działania te zakończyły się połowicznym sukcesem. Z uwagi na fiasko Europejskiej Wspólnoty Obronnej na początku lat 50. XX wieku integracja przez długi okres czasu miała przede wszystkim wymiar gospodarczy.

Powszechnie uważa się, że druga wojna światowa była bardzo istotną cezurą $\mathrm{w}$ transformacji polityki międzynarodowej. Wojna zakończyła się bowiem powstaniem politycznej próżni z uwagi na zniszczenie równowagi sił oraz trudności z osiąnnięciem generalnego traktatu pokojowego, co bardzo szybko doprowadziło do powstania dwóch rywalizujących ze sobą obozów ideologicznych (Kissinger, 1996, s. 460). Wybuch zimnej wojny nie był jedynym przejawem przeobrażeń na arenie międzynarodowej (Scott, 2008, s. 107-129). Bardzo duże znaczenie miało zbudowanie, a później dwukrotne użycie przez Stany Zjednoczone bomby atomowej przeciwko Japonii w 1945 r., co skutkowało niespotykanym w dziejach ludzkości wyścigiem zbrojeń. Wraz z uzyskaniem zdolności nuklearnych przez Związek Radziecki w 1949 r. oraz rozwojem nie tylko arsenałów atomowych ${ }^{1}$, ale także środków przenoszenia głowic, możliwość wybuchu konfliktu nuklearnego, który doprowadziłby do globalnego znisz-

${ }^{1} \mathrm{~W}$ latach 50. i 60. XX wieku kolejno status państwa nuklearnego uzyskały Wielka Brytania (1952 r.), Francja (1960 r.) i Chiny (1964 r.). 
czenia, cały czas rosła. Wyścig zbrojeń unaocznił więc potrzebę stworzenia systemu, dzięki któremu można by zapewnić bezpieczeństwo poszczególnym państwom w sytuacji realnego zagrożenia zewnętrznego, którym dla Stanów Zjednoczonych i Europy Zachodniej był Związek Radziecki.

Z punktu widzenia Europejczyków zapewnienie bezpieczeństwa w okresie tuż po zakończeniu drugiej wojny światowej miało również inny wymiar. Całkiem realnie bowiem państwa takie jak Francja czy Wielka Brytania brały pod uwagę potencjalne zagrożenie ze strony Niemiec, gdyż to właśnie państwo było winione za wybuch dwóch wojen światowych w pierwszej połowie XX wieku. Ale w odróżnieniu od Związku Radzieckiego, który bardzo szybko zaczął być postrzegany jako rywal nie tylko na kontynencie europejskim, ale dla Stanów Zjednoczonych również w wymiarze globalnym, Niemcy były uważane za potencjalnego partnera. Jak podkreślił Winston Churchill w słynnym przemówieniu na Uniwersytecie w Zurichu 19 września 1946 r.:

\begin{abstract}
„Winni muszą zostać ukarani. Niemcy muszą być pozbawieni możliwości ponownego uzbrojenia i przeprowadzenia kolejnej agresywnej wojny. Ale gdy to wszystko zostanie zrobione, jak to będzie zrobione, jak to się robi, musi być koniec zemsty. Musi mieć miejsce to, co wiele lat temu było nazwane przez Gladstone'a, »aktem błogosławionego zapomnienia«. Wszyscy musimy odwrócić się plecami od okropności przeszłości. Musimy patrzeć w przyszłość" (Churchill, 1994, s. 7).
\end{abstract}

Churchill, apelując o stworzenie Stanów Zjednoczonych Europy, widział w nich istotne miejsce dla Niemiec, gdyż partnerstwo pomiędzy Francją i Niemcami miało być fundamentem zjednoczonej Europy. Określenie w taki sposób roli Niemiec na kontynencie europejskim było świadectwem nowego spojrzenia na relacje pomiędzy nie tak odległymi rywalami. Tak jak przez stulecia rywalizacja pomiędzy Francją a Niemcami prowadziła często do konfliktów w wymiarze europejskim, tak pojednanie pomiędzy tymi dwoma państwami mogło być traktowane jako fundament pokojowej Europy. Rozwiązanie kwestii niemieckiej, poprzez kontrolowanie Niemiec, ale jednocześnie uczynienia z tego państwa partnera, miało istotne znaczenia dla zainicjowania procesów integracji europejskiej i stworzenia skutecznego systemu obrony europejskiej. Dylemat, czy Niemcy należy traktować jako byłego wroga czy przyszłego sojusznika (Jansen, De Vree, 1985, s. 61-64), z czasem zaczął tracić na znaczeniu z uwagi na rosnące zagrożenie ze strony Związku Radzieckiego. Było jasne, że Niemcy nie tylko powinny stać się partnerem, ale zacząć powoli odgrywać istotną rolę w wyłaniającej się architekturze politycznej i bezpieczeństwa w Europie. Taki sposób myślenia, partnerstwo z Niemcami przy jednoczesnym kontrolowaniu tego państwa, aby nie stało się ponownym zagrożeniem, legło u podstaw planu francuskiego ministra spraw zagranicznych Roberta Schumana, który doprowadził w 1952 r. do powstania Europejskiej Wspólnoty Węgla i Stali.

Przemówienie Churchilla było jednym z licznych apeli o zjednoczenie kontynentu europejskiego, które pojawiły się po 1945 r. Jakkolwiek miały one często zróżnicowany charakter, to jednym z podstawowych celów było doprowadzenie do osiągnięcia pokoju w Europie. Próbując określić przyszłość Europy, starano się odpowiedzieć na trzy zasadnicze pytania (Jansen, De Vree, 1985, s. 47-57). Po pierwsze, zastanawiano się nad przyczynami upadku starego systemu, czyli tego, któ- 
ry istniał w okresie międzywojennym. Odpowiadając na to pytanie, wskazywano na szereg kwestii. Przede wszystkim uważano, że nie udało się zachować pokoju z uwagi na niczym nieograniczoną rywalizację pomiędzy państwami narodowymi, ale również nie brano pod uwagę interesów zwykłych obywateli. Twierdzono wobec tego dosyć często, że nowy system powinien mieć charakter ponadnarodowy, bazować na zasadach demokratycznych i gwarantować prawa człowieka. Po drugie, starano się zidentyfikować problemy, które nie mogły być rozwiązane samodzielnie przez poszczególne państwa narodowe. Wskazywano przede wszystkim na takie wyzwania, jak odbudowa gospodarcza po zniszczeniach wojennych oraz zapewnienie bezpieczeństwa $z$ uwagi na problem niemiecki i rosnące zagrożenie ze strony Związku Radzieckiego. Po trzecie, musiano określić sposób podziału kompetencji w systemie tworzonym po drugiej wojnie światowej. Już na samym początku rozważań o potrzebie jednoczenia kontynentu europejskiego pojawiły się przeciwstawne projekty, które albo bazowały na modelu ponadnarodowym, albo międzyrządowym. Spór pomiędzy tymi dwoma sposobami myślenia widoczny był w kolejnych dekadach rozwoju procesu integracji europejskiej i jest on również obecny także w XXI wieku pomimo tego, że w obecnej Unii Europejskiej występują zarówno elementy ponadnarodowe, jak i międzyrządowe.

\section{Redefinicja polityki Stanów Zjednoczonych wobec Europy: bezpieczeństwo poprzez odbudowę gospodarczą}

Kluczowe znaczenie dla odbudowy, stabilizacji i integracji Europy po drugiej wojnie światowej miała postawa Stanów Zjednoczonych. Polityka amerykańska nie była początkowo w pełni wykrystalizowana i dopiero od 1947 r., w wyniku nasilających się różnic ze Związkiem Radzieckim, następowała jej redefinicja. Istotnymi elementami w kształtowaniu nowego stanowiska USA była widoczna przewaga militarna Związu Radzieckiego w Europie. W 1948 r. w Europie stacjonowało jedynie 200 tys. żołnierzy amerykańskich i planowano ich dalszą redukcję do poziomu 95 tys. ${ }^{2}$ Uwzględniając nawet wojska francuskie, holenderskie i brytyjskie, wielkość wojsk zachodnich nie dorównywała liczebności siłom radzieckim, których ogólną wielkość szacowano na 2 albo nawet na 4 do 5 milionów żołnierzy ${ }^{3}$. Duża część Armii Czerwonej stacjonowała w zachodniej części ZSRR i Europie Wschodniej.

W kształtowaniu nowej polityki wobec Europy istotne znaczenie odegrało zrozumienie prawdziwych intencji Józefa Stalina wobec Europy Wschodniej i Niemiec, które początkowo dla Amerykanów nie były klarowne. Już jednak pod koniec 1945 r. i w 1946 r. zrozumiano, że Związek Radziecki nie zamierza wywiązać się ze zobowiązań wynikających z porozumień zawartych w Jałcie i Poczdamie (Kugler, 1990,

${ }^{2} \mathrm{~W}$ przeciagu dwóch lat po zakończeniu drugiej wojny światowej zredukowano liczebność całej armii amerykańskiej z 12 do 1,5 miliona żołnierzy (Rupp, 2006, s. 42-43).

${ }^{3}$ Szacunki dotyczące wielkości sił radzieckich nie są jednoznaczne. Uważa się, że Armia Czerwona liczyła w końcu wojny od 12 do 15 milionów. Demobilizacja doprowadziła do zmniejszenia stanu liczebnego. Według amerykańskich danych z tego okresu uważano, że liczebność armii ZSRR była w 1948 i 1949 r. na poziomie poniżej 2 mln żołnierzy (Rupp, 2006, s. 42, 231). 
s. 12). Jasne się stało, że Polska nie będzie demokratyczna, całkowicie stając się częścią strefy wpływów ZSRR, a ponowne zjednoczenie Niemiec nie będzie możliwe z uwagi na rozpoczęcie procesu komunizowania i militaryzacji Niemiec Wschodnich okupowanych przez Armię Czerwoną. To właśnie kwestia Europy Wschodniej stała się głównym problemem w relacjach USA-ZSRR. Ewentualna natychmiastowa inwazja Związku Radzieckiego w Azji lub Europie raczej nie była brana pod uwagę, gdyż jak stwierdzono w listopadzie 1945 r. w amerykańskim raporcie szpiegowskim, Związek Radziecki nie będzie ryzykować w przeciagu co najmniej 15 lat dużego konfliktu zbrojnego z uwagi przede wszystkim na zacofanie technologiczne (LaFeber, 1985, s. 27-28).

Polityka faktów dokonanych realizowana przez Związek Radziecki doprowadziła do zaostrzenia stanowiska amerykańskiego wiosną $1946 \mathrm{r}$. i zainicjowania przez prezydenta Trumana tzw. „twardej linii” (Kissinger, 1996, s. 487-489), dzięki której udało się wymóc na Związku Radzieckim, aby wycofał swoje wojska z Iranu. Narastający konflikt z ZSRR nie był jednak postrzegany przez Trumana w kategoriach realistycznych, czyli przez pryzmat tworzenia stref wpływów i ustanowienia globalnej równowagi sił, ale bardziej idealistycznie jako walka dobra ze złem, co skutkowało czasową niemożnością ustanowienia nowego porządku światowego.

Jeszcze przed całkowitą redefinicją polityki amerykańskiej, która miała miejsce ostatecznie w 1947 r., bardzo istotne znaczenie dla ukształtowania nowego sposobu myślenia przez administrację amerykańską o relacjach ze Związkiem Radzieckim miał Dlugi telegram, który został wysłany 22 lutego $1946 \mathrm{r}$. przez młodego dyplomatę z ambasady USA w Moskwie George'a Kennana (Telegram, 1946). Adresatem tego długiego tajnego memorandum był sekretarz stanu George Marshall. Kennan w sposób niezwykle wyrazisty scharakteryzował rzeczywiste cele w polityce zagranicznej Związku Radzieckiego. Bazując na słowach Stalina z 1927 r. o wybuchu w przyszłości rywalizacji pomiędzy dwoma centrami, socjalistycznym i kapitalistycznym, o panowanie nad gospodarką światową i odwołując się przede wszystkim do ideologii komunistycznej, ostrzegał, że dla Związku Radzieckiego, „okrążonego” przez państwa kapitalistyczne, osiagnięcie z nimi stałej pokojowej koegzystencji w długiej perspektywie jest niemożliwe. Tłumaczył to również neurotycznym sposobem patrzenia przez Kreml na sprawy międzynarodowe, co było wynikiem instynktowego poczucia braku bezpieczeństwa przez Rosjan.

Dlugi telegram został przełożony na język praktyki politycznej w memorandum Harrisona Freemana Matthewsa z Departamentu Stanu z 1 kwietnia 1946 r. (Kissinger, 1996, s. 490-493; Memorandum, 1946, s. 1167-1171). Uznano w nim, że ekspansjonizmowi Związku Radzieckiego jako państwa totalitarnego powinno się przeciwdziałać przede wszystkim przy pomocy środków dyplomatycznych. Jeżeli okazałyby się one nieefektywne, to nie wykluczano użycia siły militarnej, jakkolwiek postulowano potrzebę uzyskania wcześniejszej autoryzacji ze strony Organizacji Narodów Zjednoczonych. Powyższe dokumenty świadczyły o stopniowej krystalizacji stanowiska amerykańskiego wobec Związku Radzieckiego, o czym może także świadczyć zdymisjonowanie Henry'ego Agarda Wallace'a ze stanowiska sekretarza handlu, który apelował o polityczne porozumienie z Rosją i twierdził, że systemy kapitalistyczny i komunistyczny mogą ze sobą przyjacielsko współzawodniczyć i stopniowo upodob- 
niać się do siebie (LaFeber, 1985, s. 44-45). Wydarzenie to świadczyło o podziałach w ramach administracji amerykańskiej, tym bardziej, że Wallace był politykiem wpływowym, pełniąc wcześniej funkcje sekretarza rolnictwa i wiceprezydenta u Roosvelta w latach 1941-1945. Myślenie w kategoriach realistycznych zaczęło zwyciężać nad podejściem idealistycznym (liberalnym), co było wynikiem rosnącej konfrontacji pomiędzy dwoma supermocarstwami, jakkolwiek w retoryce politycznej, nie tylko Stanów Zjednoczonych, łączono typowe kategorie realistyczne z terminami liberalnymi.

Obrazowo zaostrzającą się sytuację międzynarodową ujął Winston Churchill jako lider opozycji w Wielkiej Brytanii, który 5 marca 1946 r. wygłosił słynne przemówienie w Fulton w Stanach Zjednoczonych. Przemówienie to traktowane jest jako oznajmienie wybuchu zimnej wojny, gdyż Churchill stwierdził, że podział Europy jest faktem z uwagi na opuszczenie się żelaznej kurtyny i stworzenie radzieckiej strefy wpływów w Europie Środkowej i Wschodniej ${ }^{4}$. Churchill nie skupił się jedynie na diagnozie ówczesnej sytuacji międzynarodowej, ale apelował o podjęcie określonych działań. Apelował o nową jedność Europy i bardzo wyraźnie podkreślał rolę Stanów Zjednoczonych we współpracy z Wielką Brytanią w rozwiązywaniu problemów międzynarodowych. Opowiadał się jednak przeciwko równowadze sił. Akcentował natomiast konieczność wspólnego działania demokracji zachodnich zgodnie z zasadami Karty Narodów Zjednoczonych. Z drugiej jednak strony, ukazując perspektywę radzenia sobie z zagrożeniem ze strony Związku Radzieckiego, Churchill podkreślał, że siła jest jedyną rzeczą, którą Rosjanie podziwiają, a nie szanują słabości, przede wszystkim w sferze militarnej. Jakkolwiek przemówienie Churchilla wywołało zróżnicowane reakcje, to jednak wyraził on to, co w tamtym okresie było już dyskutowane w ramach administracji amerykańskiej, ale nie było upubliczniane, jak chociażby Dtugi telegram Kennana ${ }^{5}$.

Józef Stalin w wywiadzie dla dziennika „Prawda” uznał przemówienie Churchilla za wyraz rasistowskiej teorii, że ci, którzy mówią po angielsku powinni rządzić pozostałymi narodami świata (LaFeber, 1985, s. 39). Jednocześnie stwierdził, że jest ono świadectwem przygotowywania wojny ze Związkiem Radzieckim. Tego rodzaju retoryka ze strony Stalina ${ }^{6}$ była potwierdzeniem zaostrzenia się relacji pomiędzy Związkiem Radzieckim i Stanami Zjednoczonymi oraz w pełni unaoczniła potrzebę redefinicji amerykańskiej polityki zagranicznej oraz konieczność integracji pomiędzy demokratycznymi państwami europejskimi. Jak podkreślił w grudniu 1947 r. brytyjski minister spraw zagranicznych Ernest Bevin, z uwagi na to, że Związek Radziecki nie będzie w sposób rozsądny rozwijał relacji z Zachodem, przetrwanie Europy Zachod-

${ }^{4}$ „Od Szczecina nad Bałtykiem do Triestu nad Adriatykiem opuściła się żelazna kurtyna w poprzek kontynentu. Za tą linią leżą wszystkie stolice starych państw Europy Środkowej i Wschodniej. Warszawa, Berlin, Praga, Wiedeń, Budapeszt, Belgrad, Bukareszt i Sofia, wszystkie te sławne miasta i ludność wokół nich leżą w czymś, co muszę nazwać radziecką strefą i wszystkie podlegają w takiej czy innej formie nie tylko wpływom radzieckim, ale w bardzo wysokiej i, w wielu przypadkach, zwiększającej się kontroli ze strony Moskwy" (Churchill, 1946).

${ }_{5}^{5}$ Bardzo szczegółowa analiza okoliczności wygłoszenia przemówienia przez Winstona Churchilla w Fulton i reakcji na nie zamieszczona jest w: Ramsden, 1999, s. 15-47.

${ }^{6}$ Jedno z przemówień Józefa Stalina, tzw. wyborcze z 9 lutego 1946 r., jest uważane, oprócz przemówienia Churchilla, za deklarację zimnej wojny (LaFeber, 1985, s. 38). Tekst przemówienia w: Stalin, 1954, s. 19-43. 
niej jest zależne od stworzenia jakiejś formy unii z poparciem Stanów Zjednoczonych (Rupp, 2006, s. 44).

Pierwszym oficjalnym zwiastunem nowego podejścia Stanów Zjednoczonych do polityki międzynarodowej była doktryna Trumana, która została ogłoszona przez amerykańskiego prezydenta w przemówieniu do obu izb Kongresu 12 marca 1947 r. Miała ona niezwykle istotne znaczenie, gdyż już w toku jej przygotowań określono aktywny sposób przeciwdziałania ekspansjonizmowi Związku Radzieckiego. W styczniu 1946 r. w dokumencie Departamentu Stanu przeznaczonym dla prasy w sprawie sytuacji w Grecji stwierdzono, że pomoc gospodarcza ma doprowadzić do natychmiastowej poprawy sytuacji gospodarczej, co stworzy korzystne warunki dla przeprowadzenia demokratycznych wyborów (Department of State, 1946). Dzięki wyborom nastąpi poprawa sytuacji politycznej, a ta z kolei przyczyni się znacznie w perspektywie długoterminowej do ożywienia gospodarczego i przyszłej stabilizacji. Strategia amerykańska sprowadzała się więc do używania instrumentów gospodarczych (pomoc gospodarcza), do osiagania celów gospodarczych (stabilizacja i ożywienie gospodarcza) i przez to politycznych (demokratyzacja i stabilizacja polityczna). Dzięki takim działaniom miało dojść do powstrzymania ekspansji komunizmu.

Taki sposób myślenia został bardzo wyraźnie wyakcentowany 27 lutego $1946 \mathrm{r}$. podczas spotkania prezydenta Harry'ego Trumana, sekretarza stanu George'a Marshalla i podsekretarza stanu Deana Achesona z delegacją Kongresu (Meeting notes, 1947). Świat, w opinii administracji amerykańskiej, został zdominowany przez dwie wielkie potęgi. Jak twierdzono, taka polaryzacja nie miała miejsca od czasów Aten i Sparty oraz Rzymu i Kartaginy. Rodziło to problem bezpieczeństwa Stanów Zjednoczonych, gdyż obawiano się, że komunizm mógłby w przyszłości kontrolować nawet dwie-trzecie świata. Udzielenie pomocy Grecji miało więc na celu powstrzymanie ekspansji komunizmu z uwagi na dążenia Moskwy do przejęcia kontroli nad tym państwem. Jednocześnie chodziło o przeciwdziałanie okrążeniu Turcji, gdyż jak podkreślono, Związek Radziecki systematycznie dążył do otaczania Turcji i Niemiec przez kontrolowane przez siebie państwa. Polityka powstrzymywania była traktowana jako konfrontacja pomiędzy demokracją a komunizmem, czyli bardziej w kategoriach wartości a nie siły militarnej. Starcie między USA a ZSRR było ukazywane jako przede wszystkim konflikt ideologiczny, stąd duży nacisk na używanie instrumentów gospodarczych do osiaggania celów politycznych. Kwestią sporną pozostaje ocena polityki amerykańskiej utożsamianej z prezydentem Harrym Trumanem z punktu widzenia teorii stosunków międzynarodowych. Biorąc pod uwagę zróżnicowane opinie w tej sprawie ${ }^{7}$, wydaje się, że najbezpieczniej jest okre-

${ }^{7} \mathrm{~W}$ połowie lat 90 . Truman był przede wszystkim postrzegany jako realista a nie idealista. W taki sposób podchodził do niego Henry Kissinger i Thomas Zeiler, który podkreślał, że w formułowaniu polityki handlowej Trumana dominował realizm i kategoria bezpieczeństwa narodowego a nie idealizm i teoria ekonomiczna. Na początku XXI wieku sposób ujęcia Trumana przez historiografię uległ zmianie, gdyż zaczęto się koncentrować na ideologicznych korzeniach jego polityki. Na przykład Arnold Offner argumentował, że wizja świata Trumana miała charakter „zaściankowy i nacjonalistyczny" i nacechowana była bezkrytyczną wiarą w wyższość wartości amerykańskich i interesów polityczno-ekonomicznych. Zupełnie przeciwstawny punkt widzenia zaprezentowała Elizabeth Edwards Spalding, która uważała, że Truman stworzył podstawy pod myślenie w kategoriach liberalnych (liberal internationalism). W takim sposobie myślenia istotną rolę odgrywała ONZ, 
ślać postawę Trumana jako mieszankę realizmu i podejścia liberalnego. Polityka powstrzymywania była elementem rywalizacji ze Związkiem Radzieckim i została ona później uzupełniona o NATO, co można kwalifikować jako podejście realistyczne. Bazowała ona jednak na idealistycznym przekonaniu o sile państw demokratycznych i możliwości osiągnięcia pokoju międzynarodowego poprzez rozprzestrzenianie demokracji ${ }^{8}$. Takie przekonanie legło u podstaw doktryny Trumana, ale wprost było także wyrażone w przemówieniu wygłoszonym przez Harry'ego Trumana 20 stycznia 1949 r. na inaugurację drugiej kadencji. Stwierdził on dobitnie: „Demokracja uważa, że wolne narody mogą rozstrzygnąć różnice sprawiedliwie i utrzymać trwały pokój" (Truman's inaugural address, 1949).

Spotkanie z 27 lutego 1946 r. w Białym Domu pomogło prezydentowi Trumanowi w przekonaniu Kongresu do akceptacji programu pomocy dla Grecji i Turcji oraz podjęcia bardziej aktywnej polityki wobec ekspansji komunizmu (Kissinger, 1996, s. 493-494). Spotkanie było niezwykle istotne, gdyż obie izby Kongresu były kontrolowane przez republikańskich izolacjonistów ${ }^{9}$. Po zyskaniu poparcia ze strony kongresmenów ${ }^{10}$, ostatecznie prezydent Harry Truman wystąpił 12 marca 1947 r. przed obiema izbami Kongresu z orędziem, w którym została ogłoszona doktryna, nazwana później doktryną Trumana (Address of the President, 1947). Była ona oficjalnym zwiastunem nowej polityki amerykańskiej. Truman poprosił w nim o udzielenie $400 \mathrm{mln}$ dolarów pomocy dla Grecji i Turcji, aby przyczynić się do stabilizacji gospodarczej i politycznej obu państw. Zgodnie z deklaracją samego prezydenta, celem polityki amerykańskiej było wspieranie wolnych narodów, które przeciwstawiają się działaniom ze strony uzbrojonej mniejszości lub presji zewnętrznej, która była utożsamiana z działalnością reżimów totalitarnych. Chodziło więc o przeciwdziałanie narzucaniu poszczególnym państwom reżimów totalitarnych, co jak podkreślał Truman, miało miejsce w odniesieniu do takich państw, jak Polska, Rumunia i Bułgaria wbrew postanowieniom z Jałty. Strategia amerykańska bazowała na przekonaniu, że działania Związku Radzieckiego w wyniku bezpośredniej lub pośredniej agresji naruszają fundamenty pokoju międzynarodowego i przez to bezpieczeństwo Stanów Zjednoczonych. Uzasadnienie nowej polityki amerykańskiej nie miało charakteru realistycznego, gdyż Truman nie odwoływał się w swoim przemówieniu do takich kategorii, jak na przykład równowaga sił. Prezydent ukazywał rywalizację ze Związkiem Radziec-

ale przede wszystkim dużą wagę przywiązywano do walki państw demokratycznych z tyranią. Doktryna Trumana była traktowana jako centralna idea, dzięki której narody tworzyły warunki własnego funkcjonowania bez zewnętrznego przymusu (McVety, 2012, s. 87-107).

8 Jednym z podstawowych haseł teorii liberalnej stosunków międzynarodowych jest „pokój przez demokrację" - jest to tzw. teoria demokratycznego pokoju (na temat tej teorii patrz m.in. Czaputowicz, 2008, s. 132-137).

${ }^{9}$ Podczas spotkania w Białym Domu na czele delegacji Kongresu stał bardzo wpływowy senator Arthur Vandenberg, od 1947 r. przewodniczący senackiej komisji stosunków zagranicznych. Był on wcześniej izolacjonista, jednak 10 stycznia 1945 r. wygłosił przemówienie, które uważane jest za konwersję na internacjonalizm (Arthur Vandenberg).

${ }^{10}$ Sam Vandenberg podkreślał, ze uzyskanie poparcia Kongresu dla pomocy dla Grecji i Turcji nie będzie proste. Joseph Nye tak referuje odpowiedź Vandenbergha na pytanie Trumana: „Vandenbergh odpowiedział, że Truman musiałby »przerazić piekło«, by uzyskać poparcie Kongresu dla takiego odejścia od tradycyjnej linii amerykańskiej polityki zagranicznej” (Nye, 2009, s. 180). 
kim, jakkolwiek nazwa tego państwa nie pojawiła się w przemówieniu, w kategoriach walki pomiędzy dwoma systemami wartości, pomiędzy demokracją a totalitaryzmem. Wsparcie dla Grecji i Turcji było podyktowane obawami o możliwość wpadnięcia tych państw do radzieckiej strefy wpływów, co pozwoliłoby ZSRR na swobodny dostęp do Morza Śródziemnego. Najbardziej problematyczna sytuacja miała miejsce w Grecji, która targana była w latach 1946-1949 wojną domową pomiędzy partyzantką komunistyczną a rządzącymi rojalistami. Jednak zwycięstwo komunistów w Grecji mogło mieć negatywny wpływ na rozwój sytuacji w Turcji.

Doktryna Trumana miała istotne znaczenie nie tylko z punktu widzenia przeobrażeń polityki zagranicznej Stanów Zjednoczonych, ale również dla rozwoju sytuacji na kontynencie europejskim. Jakkolwiek nie obyło się bez kontrowersji, to doktryna Trumana była punktem zwrotnym w określaniu międzynarodowego zaangażowania Stanów Zjednoczonych. Oznaczało to, że Amerykanie nie tylko nie powrócą po drugiej wojnie światowej do polityki izolacjonizmu, ale co więcej, w sposób aktywny będą dążyć do walki z komunizmem w różnych częściach świata. Był to więc sygnał świadczący o rozpoczęciu globalnej rywalizacji ze Związkiem Radzieckim, w której Europa odgrywała szczególnie istotną rolę. Doktryna Trumana była pierwszym elementem w nowym podejściu Stanów Zjednoczonych do kwestii bezpieczeństwa międzynarodowego. Przyjęta strategia polegała przede wszystkim na użyciu instrumentów gospodarczych do osiągnięcia celów politycznych. Bezpieczeństwo było więc pochodną stabilizacji gospodarczej i rozwoju demokracji. Bardzo istotnym uzupełnieniem takiego sposobu myślenia było późniejsze ustanowienie Sojuszu Atlantyckiego, co oznaczało, że Amerykanie nie wykluczali także zastosowania siły militarnej, aby zapewnić państwom europejskim bezpieczeństwo. To właśnie Stany Zjednoczone jako supermocarstwo dysponujące bronią atomową stały się odpowiedzialne za bezpieczeństwo europejskie.

Rozwinięciem doktryny Trumana był plan Marshalla ogłoszony przez amerykańskiego sekretarza stanu w przemówieniu wygłoszonym na Uniwersytecie Harwardzkim 5 czerwca 1947 r. George Marshall rozszerzył zakres geograficzny amerykańskiej pomocy gospodarczej w celu gospodarczej i politycznej stabilizacji kontynentu europejskiego. W sposób bardzo wyraźny określił cele planu:

„,...] Stany Zjednoczone powinny uczynić wszystko, co jest możliwe do zrobienia, aby pomóc w powrocie do normalnego zdrowia gospodarczego na świecie, bez którego nie będzie politycznej stabilizacji i trwałego pokoju. Nasza polityka nie jest skierowana przeciwko jakiemukolwiek państwu lub doktrynie, ale przeciwko głodowi, biedzie, desperacji i chaosowi. Jej celem powinno być ożywienie funkcjonującej gospodarki na świecie, aby pozwolić na wyłonienie się politycznych i społecznych warunków, w których mogą istnieć wolne instytucje. [...] Jakikolwiek rząd, który zechce pomóc w zadaniu odbudowy może liczyć na pełną współpracę, jestem pewien, ze strony rządu Stanów Zjednoczonych. Jakikolwiek rząd, który manipuluje, aby zablokować odbudowę innych państw nie może oczekiwać pomocy z naszej strony. Co więcej, rządy, partie polityczne lub grupy, które dążą do przedłużenia ludzkiego cierpienia, aby uzyskać polityczne lub inne korzyści, napotkają sprzeciw ze strony Stanów Zjednoczonych" (Speech by George C. Marshall, 1947, s. 1159-1160). 
Przyjęcie planu Marshalla było związane z akceptacją kilku istotnych warunków, które były sformułowane w dalszych rozmowach pomiędzy zainteresowanymi państwami a Stanami Zjednoczonymi. Państwa europejskie musiały (Jansen, De Vree, 1985, s. 65):

1) zgodzić się co do wielkości pomocy i podziału jej pomiędzy poszczególne państwa;

2) przygotować program ożywienia gospodarczego;

3) osiagnąc samowystarczalność do 1952 r.;

4) zlikwidować bariery handlowe;

5) utworzyć organizację międzynarodową odpowiedzialną za wprowadzenie w życie programu pomocy.

Plan Marshalla bazował na podobnej strategii, która była już zwerbalizowana w ramach doktryny Trumana. Bezpieczeństwo, które było podstawową chronioną wartością, było ujmowane szeroko. Jego zapewnienie nie tylko miało być osiągnięte dzięki środkom militarnym, ale również gospodarczym. Dzięki odbudowie po zniszczeniach wojennych i stworzeniu podstaw rozwoju gospodarczego miała następować stabilizacja gospodarcza poszczególnych państw jako warunek niezbędny stabilizacji politycznej i konsolidacji demokracji. Stabilizacja była kluczem dla zapewnienia bezpieczeństwa, gdyż niwelowała możliwość ekspansji komunizmu.

Plan Marshalla był istotnym impulsem na rzecz jednoczenia kontynentu europejskiego. Po pierwsze, doprowadził on do powstania 16 kwietnia $1948 \mathrm{r}$. Organizacji Europejskiej Współpracy Gospodarczej (OEEC), w skład której weszły państwa europejskie, które przyjęły plan Marshalla. Jakkolwiek organizacja ta nie spełniła nadziei zwolenników ściślejszej integracji, zarówno federalistów, jak i przedstawicieli podejścia funkcjonalistycznego, czyli stopniowej ewolucyjnej integracji, to jednak unaoczniła fakt współzależności pomiędzy gospodarkami państw europejskich (Urwin, 1995, s. 21-22). Ograniczenia OEEC wynikały z braku politycznych aspiracji oraz w zakresie współpracy gospodarczej, gdyż organizacja ta przyczyniła się jedynie do liberalizacji handlu, przede wszystkim w odniesieniu do znoszenia ograniczeń ilościowych. Po drugie, dzięki planowi Marshalla nastąpiła odbudowa i ożywienie gospodarcze w Europie, stworzono więc niezbędne warunki dla podjęcia działań integracyjnych. Plan Marshalla ostatecznie przypieczętował, przesądzony już wcześniej, podział Europy, gdyż państwa leżące w strefie wpływów Związku Radzieckiego z uwagi na dyktat Moskwy nie mogły skorzystać z oferty amerykańskiej pomimo zainteresowania planem ${ }^{11}$.

Nowa polityka amerykańska, w postaci doktryny Trumana i planu Marshalla, została uzupełniona i w pełni wyartykułowana w anonimowym wówczas artykule Źródta radzieckiego zachowania, który został opublikowany w lipcu 1947 r. w czasopiśmie „Foreign Affairs”. Autorem tego artykułu był George Kennan, który pełnił w tamtym

${ }^{11}$ Poszczególne państwa Europy Środkowej i Wschodniej, między innymi Polska, Węgry i Czechosłowacja, rozważały możliwość skorzystania z pomocy w ramach planu Marshalla. Nie mogły tego zrobić z uwagi na nacisk Moskwy. Znamienne w tym zakresie słowa wygłosił minister spraw zagranicznych Czechosłowacji Jan Masaryk, który w lipcu 1947 r. po wizycie w Moskwie stwierdził: „Pojechałem do Moskwy jako minister spraw zagranicznych niezależnego suwerennego państwa; wróciłem jako lokaj rządu sowieckiego" (Lipgens, 1982, s. 485). 
okresie funkcję szefa Zespołu Planowania Politycznego w Departamencie Stanu. Artykuł Kennana, wprowadzając termin polityki powstrzymywania, stał się podstawą działań na arenie międzynarodowej dla kilku pokoleń Amerykanów (Kissinger, 1996, s. 495-496). Kennan, poddając analizie ideologiczne podstawy polityki Związku Radzieckiego, wskazał, że bazuje ona na przekonaniu o wrodzonym antagonizmie pomiędzy kapitalizmem a socjalizmem oraz o nieomylności Kremla (X, 1987, s. 852-868). Proponował więc, że „,...] głównym elementem jakiejkolwiek polityki Stanów Zjednoczonych wobec Związku Sowieckiego musi być długoterminowe, cierpliwe, ale stanowcze i czujne powstrzymywanie rosyjskich tendencji ekspansjonistycznych". Definiując politykę powstrzymywania Kennan stwierdził, że była ona ,„[...] pomyślana jako konfrontacja odpowiednimi siłami z Rosjanami wszędzie tam, gdzie wykazują oni chęć naruszania interesów pokojowego i stabilnego świata".

Jakkolwiek polityka powstrzymywania Kennana była przyjmowana przez kolejne administracje amerykańskie przez cały okres zimnej wojny aż do 1989 r., to jednak po jej ogłoszeniu nie obyło się bez kontrowersji (Kennan and Containment). W samej administracji Trumana zyskała na znaczeniu bardziej konfrontacyjna wersja polityki powstrzymywania. Kennan traktował zagrożenie ze strony Związku Radzieckiego w kategoriach politycznych i wobec tego opowiadał się za stosowaniem instrumentów gospodarczych lub za prowadzeniem wojny psychologicznej. Jednak jego następca na stanowisku szefa Zespołu Planowania Politycznego Paul Nitze traktował zagrożenie radzieckie przede wszystkim jako militarne, co doprowadziło do przyjęcia w $1950 \mathrm{r}$. ściśle tajnego raportu Narodowej Rady Bezpieczeństwa nr 68 (NSC 68), który może być traktowany jako oficjalna wykładnia strategii USA w okresie zimnej wojny (Kissinger, 1996, s. 504). Dokument nr 68 łączył w sobie myślenie w kategoriach realistycznych i liberalnych (A report, 1950). Z jednej bowiem strony, postulowano w nim znaczne zwiększenie potencjału militarnego Stanów Zjednoczonych. $Z$ drugiej jednak strony, walka z komunizmem, która uzyskała wymiar globalny, była charakteryzowana w kategoriach moralnych jako obrona wartości i instytucji demokratycznych. Pierwotna koncepcja polityki powstrzymywania Kennana była także krytykowana jako zbyt defensywna. Podczas kampanii prezydenckiej w 1952 r. John Foster Dulles, który w latach 1953-1959 pełnił funkcję sekretarza stanu u prezydenta Dwighta Eisenhowera, uważał, że polityka amerykańska powinna iść dalej (Kennan and Containment). Jej celem nie powinno być jedynie powstrzymywanie, ale zmuszenie sił radzieckich do wycofania i ostatecznie wyzwolenie Europy Wschodniej.

Zarówno doktryna Trumana, jak i plan Marshalla miały służyć powstrzymywaniu ekspansji komunizmu przy użyciu instrumentów gospodarczych, jakkolwiek głównym celem planu Marshalla była odbudowa gospodarcza państw europejskich po zniszczeniach wojennych. Odbudowa gospodarcza i powstrzymywanie komunizmu były celami bardzo mocno ze sobą powiązanymi, wręcz współzależnymi. Ostatecznym celem planu Marshalla było ustanowienie zachodniej wspólnoty narodów, które połączone byłyby podobnymi wartościami, wspólnymi interesami, bezpieczeństwem zbiorowym i silnymi więzami handlowymi rozwijanymi w otwartym systemie gospodarczym (Kugler, 1990, s. 17-18). Dzięki powstrzymywaniu zapewniano państwom Europy Zachodniej bezpieczeństwo niezbędne dla realizacji programu odbudowy gospodarczej. 


\section{Działania państw Europy Zachodniej w zapewnieniu własnego bezpieczeństwa}

Nowa polityka amerykańska oraz zmieniające się uwarunkowania na kontynencie europejskim miały wpływ na koncepcje i działania państw Europy Zachodniej, w szczególności dwóch potęg, tj. Wielkiej Brytanii i Francji, w określaniu zakresu i sposobów kształtowania współpracy pomiędzy sobą. W centrum zainteresowania znalazły się przede wszystkim problemy odbudowy gospodarczej i zapewnienia bezpieczeństwa. Jednak w myśleniu zarówno Brytyjczyków, jak i Francuzów bezpieczeństwo europejskie było postrzegane nie tylko w kontekście rosnącego zagrożenia ze strony Związku Radzieckiego, ale również brano pod uwagę konieczność przeciwdziałania potencjalnemu wzrostowi potęgi Niemiec. Kwestia określenia przyszłości Niemiec Zachodnich, które były początkowo traktowane jako potencjalne zagrożenia, ale też ewentualny przyszły partner, stała się jednym z centralnych problemów, wokół którego kształtowała się debata dotycząca bezpieczeństwa i integracji europejskiej.

Początków współpracy państw Europy Zachodniej w zakresie bezpieczeństwa należy szukać w powrocie do bliższych kontaktów pomiędzy Wielką Brytanią i Francją, które to państwa po zakończeniu drugiej wojny światowej demonstrowały odmienne interesy na Bliskim Wschodzie i w Niemczech (Parzymies, 1999, s. 89). Istotnymi impulsami do kooperacji był rosnący podział Europy z uwagi na zainicjowanie zimnej wojny oraz apele na rzecz integracji europejskiej. W obu przypadkach problem zapewnienia bezpieczeństwa odgrywał kluczową rolę. Podział Europy związany był z realnym zagrożeniem ze strony Związku Radzieckiego i koniecznością przeciwdziałania jemu. Dążenia na rzecz jedności europejskiej miały na celu ustanowienie pokojowej Europy po katastrofalnych doświadczeniach dwóch wojen światowych i początkowo związane były między innymi z rozwiązaniem kwestii niemieckiej.

Bezprecedensowa pomoc amerykańska w postaci planu Marshalla była w pewnej mierze uzależniona od stworzenia przez Europejczyków systemu obronnego w celu przeciwdziałania zagrożeniu radzieckiemu (Jansen, De Vree, 1985, s. 73-74). Jednocześnie Stany Zjednoczone opowiadały się za objęciem Niemiec Zachodnich planem Marshalla i włączeniem do zachodniego systemu obronnego. Dla Francji ewentualne ponowne uzbrojenie Niemiec nie było łatwe do zaakceptowania. Francja skłonna była nawet do odrzucenia planu Marshalla, jeżeli nie otrzymałaby należytych gwarancji od Stanów Zjednoczonych i Wielkiej Brytanii w kwestii zagrożenia niemieckiego. Nie ulega wątpliwości, że Francja nie była przygotowana tuż po zakończeniu drugiej wojny światowej na pojednanie z Niemcami. Wręcz przeciwnie, jak podkreśla Michael Sutton, Francja z obsesją podchodziła do demonicznych Niemiec i dopiero pod koniec lat 40. uznała, jak inne państwa, że głównym zagrożeniem jest jednak Związek Radziecki (Sutton, 2007, s. 24-25). Wielka Brytania popierała stanowisko Francji, gdyż obawiała się, że jeżeli Francja odmówi udziału w planie Marshalla, to Stany Zjednoczone wycofają się z programu pomocy (Jansen, De Vree, 1985, s. 73-74).

Zbliżenie stanowisk Francji i Wielkiej Brytanii nastapiło jeszcze przed ogłoszeniem planu Marshalla i doprowadziło do podpisania 4 marca 1947 r. Traktatu z Dunkierki, który zapoczątkował budowę zachodnioeuropejskiego systemu obronnego ${ }^{12}$.

12 Początkowo jednak intencje Wielkiej Brytanii miały bardziej charakter krótkoterminowy niż długoterminowy. Oprócz wspomnianych powyżej czynników, brytyjski minister spraw zagranicz- 
Porozumienie było rezultatem szybkich negocjacji pomiędzy oboma państwami, gdyż formalna propozycja pojawiła się w liście nowego francuskiego premiera i jednocześnie ministra spraw zagranicznych Léona Bluma skierowanego do rządu Wielkiej Brytanii (Adamtwaite, 1986, s. 15-16; Baylis, 1984, s. 617-619; Sutton, 2007, s. 24-25). Traktat, który wszedł w życie 8 września 1947 r. na okres 50 lat, był zawarty w celu przeciwdziałania ponowieniu się zagrożenia ze strony Niemiec (Treaty of Alliance, 1947, s. 189-194). Artykuł II przewidywał gwarancje bezpieczeństwa, zgodnie z którymi w przypadku podjęcia działań przeciwko Niemcom, jeżeli te stwarzałyby zagrożenie lub w sytuacji ataku ze strony Niemiec, państwa miały natychmiast udzielić sobie pomocy militarnej lub w innej formie.

Wielka Brytania, po podpisaniu porozumienia z Francją, dążyła do unormowania relacji z mniejszymi państwami Europy Zachodniej, przede wszystkim Belgią i Holandią, początkowo chcąc oprzeć je na modelu sojuszu określonego w Traktacie z Dunkierki (Baylis, 1984, s. 617-622). Było to zgodne z dążeniami samej Belgii, która jeszcze w trakcie drugiej wojny światowej i po niej chciała, aby to właśnie Wielka Brytania stała się liderem w tworzeniu powojennego bloku państw. Po ogłoszeniu planu Marshalla, pomimo nacisków ze strony Belgii, brytyjski minister spraw zagranicznych Ernest Bevin akcentował przede wszystkim potrzebę skoncentrowania się na kwestiach odbudowy gospodarczej. Wynikało to przede wszystkim z pogarszającego się stanu gospodarki brytyjskiej i innych państw europejskich. Bevin uważał bowiem, że poważne trudności gospodarcze mogą doprowadzić nawet do rewolucji, co jego zdaniem było największym zagrożeniem dla bezpieczeństwa Europy Zachodniej (Baylis, 1993, s. 64). Problem zapewnienia bezpieczeństwa jednak dosyć szybko powrócił, co wynikało z wielu przesłanek. Po pierwsze, był on wynikiem pozytywnej reakcji państw Europy Zachodniej na ofertę amerykańską, za czym kryła się aktywność Bevina, ale również jego francuskiego odpowiednika Georges'a Bidaulta. Po drugie, Stany Zjednoczone, co zakomunikował Marshall Bevinowi, uzależniały możliwość ustanowienia rozwiązań atlantyckich w zakresie bezpieczeństwa od stworzenia przez państwa Europy Zachodniej sojuszu wojskowego (Sutton, 2007, s. 26). Takie postawienie sprawy przez samych Amerykanów miało duże znaczenie, gdyż w Wielkiej Brytanii widoczny był spór, który korzeniami sięgał drugiej wojny światowej, pomiędzy podejściami europejskim i atlantyckim (Baylis, 1993, s. 62). Ministerstwo spraw zagranicznych opowiadało się przede wszystkim za obraniem przez Wielką Brytanię roli przywódczej w Zachodniej Europie, podczas gdy szefowie sztabu uważali, że należy koncentrować się na stosunkach atlantyckich. Po trzecie, wpływ na działania Wielkiej Brytanii i innych państw miały pogarszające się relacje ze Związkiem Radzieckim i komunistyczny przewrót w Czechosłowacji w lutym 1948 r., który stał się symbolem konsolidacji bloku wschodniego. Istotne znaczenie dla wysunięcia przez Bevina najistotniejszej brytyjskiej inicjatywy na rzecz jedności europejskiej miało przede wszystkim fiasko spotkania ministrów spraw zagranicznych USA, ZSRR, Wielkiej Brytanii i Francji w Londynie na przełomie listopada i grudnia 1947 r., które dotyczyło głównie kwestii zjednoczenia Niemiec.

nych Ernest Bevin dążył do ograniczenia wpływu francuskiej Partii Komunistycznej na politykę wewnętrzną oraz chciał przeciwdziałać przyciaganiu Francji przez Związek Radziecki (Greenwood, 1983, s. 49). 
17 grudnia 1947 r., dwa dni po zakończeniu spotkania w Londynie, Bevin odbył dwa istotne spotkania (Baylis, 1984, s. 619-620). Francuskiego ministra spraw zagranicznych Bidaulta przekonywał do stworzenia jakiejś formy elastycznej federacji w Europie Zachodniej, jakkolwiek przy pomocy Stanów Zjednoczonych. Rozmawiając z amerykańskim sekretarzem stanu Marshallem, opowiedział się za ustanowieniem duchowej federacji Zachodu, a nie formalnego sojuszu, składającej się ze Stanów Zjednoczonych, Wielkiej Brytanii, Francji, Włoch i dominiów. Reakcja Marshalla była w zasadzie pozytywna, jakkolwiek chciał on poznać więcej szczegółów. Oba te spotkania świadczyły o istotnej zmianie polityki Wielkiej Brytanii, dla której Związek Radziecki stawał się głównym zagrożeniem a Niemcy zaczęły być traktowane jako przyszły partner. Następował więc istotny odwrót od logiki, która legła u podstaw Traktatu z Dunkierki. O zmianie polityki brytyjskiej może świadczyć tajne memorandum, które zostało przekazane przez Bevina Marshallowi (Insall, Salmon, 2015, s. X). W dokumencie tym scharakteryzowano opinie radzieckiego ministra spraw zagranicznych Wiaczesława Mołotowa i jego zastępcy Andrieja Wyszynskiego wyrażone podczas spotkania z ambasadorami państw słowiańskich w Londynie. Stwierdzili oni bardzo wyraźnie, że potęgi zachodnie mogą uważać Europę Wschodnią za straconą na zawsze. Co więcej, podkreślili, że nawet, jeżeli dojdzie do stworzenia sojuszu przez USA i Wielką Brytanię, który może doprowadzić do ataku na ZSRR, to jednak z czasem rozpadnie się on z powodów politycznych i gospodarczych (Enclosure, 2015, s. 7-9).

Wydarzenia z początku 1948 r. potwierdzały narastający konflikt ze Związkiem Radzieckim, który stawał się głównym zagrożeniem dla Stanów Zjednoczonych i Europy Zachodniej. Szczególnie istotne znaczenie dla Zachodu miał praski zamach stanu w lutym 1948 r., dzięki któremu komuniści przejęli władzę w Czechosłowacji. Symbolem komunistycznego terroru stała się niewyjaśniona śmierć czechosłowackiego ministra spraw zagranicznych Jana Masaryka 10 marca 1948 r. Miała ona także poważne konsekwencje polityczne. Przyśpieszyła ona wejście w życie planu Marshalla oraz włączenie Niemiec Zachodnich do Zachodu (Kaplan, 2007, s. 51). Co więcej, była istotnym katalizatorem w tworzeniu rozwiązań instytucjonalnych, gdyż doprowadziła do powstania Paktu Brukselskiego i wpłynęła na decyzję Amerykanów o powołaniu Sojuszu Atlantyckiego. Wydarzenia w Czechosłowacji były przykładem komunistycznej konsolidacji władzy w państwach Europy Wschodniej kontrolowanych przez Związek Radziecki, co miało miejsce generalnie w latach 1947-1948. Można je również było traktować jako preludium do przejęcia władzy przez komunistów w Europie Zachodniej (Kaplan, 2007, s. 49). W wyborach we Włoszech w kwietniu 1948 r. drugą siłą polityczną po chrześcijańskich demokratach stali się komuniści, którzy otwarcie podkreślali, że przyszłością Włoch jest Wschód a nie Zachód, bo w przeciwnym razie dojdzie do wybuchu wojny (Einaudi, 1948, s. 350-351). Rosjanie wywierali nacisk na Norwegię, aby to państwo podpisało akt o nieagresji, a dowódca sił amerykańskich w Niemczech generał Lucius Clay ostrzegał przed nagłym atakiem ze strony Związku Radzieckiego (Kaplan, 2007, s. 49). Potwierdzeniem tego konfrontacyjnego podejścia Stalina wobec rozwiązania kwestii niemieckiej była blokada Berlina Zachodniego, która trwała od czerwca 1948 r. do maja 1949 r. i przyśpieszyła prace nad stworzeniem Sojuszu Atlantyckiego (Sloan, 2010, s. 18). Blokada Berlina Zachodniego potwier- 
dziła przekonanie Amerykanów o długoterminowym ekspansjonistycznym podejściu Związku Radzieckiego, ale z drugiej strony ukazała, że Moskwa, przyjmując taktykę niskiego ryzyka w trakcie blokady, próbowała wywierać wpływ, nie dążąc od razu do konfrontacji militarnej (Shlaim, 1983, s. 287-292).

Napięta sytuacja w Europie miała wpływ na państwa zachodnie i podpisanie 17 marca 1948 r. przez Wielką Brytanię, Francję, Belgię, Holandię i Luksemburg Traktatu o wspótpracy gospodarczej, społecznej i kulturalnej oraz zbiorowej samoobronie (Treaty, 2009). Traktat po okresie ratyfikacji wszedł w życie 25 sierpnia 1948 r. i doprowadził do stworzenia Organizacji Traktatu Brukselskiego, która była również nazywana Unią Zachodnią ${ }^{13}$. Negocjacje nad Traktatem Brukselskim ukazały różnice zdań przede wszystkim w zakresie określenia zagrożenia dla powstającego sojuszu wojskowego. Państwa Beneluksu wyraźnie sprzeciwiały się określeniu Niemiec jako potencjalnego zagrożenia i opowiadały się za możliwością współpracy z odrodzonymi Niemcami (Baylis, 1984, s. 626). Podobną opinię wyrażały również Stany Zjednoczone, na pomoc których liczyły państwa europejskie w przypadku ataku. Przeciwnego zdania była Francja, a Wielka Brytania przyjęła kompromisowe podejście. Ostatecznie w Traktacie nie wskazano ani na Niemcy, ani na Związek Radziecki jako potencjalnego agresora. W artykule 7 wspomniano jedynie o możliwości odbycia konsultacji pomiędzy państwami członkowskimi w przypadku odnowienia się agresywnej polityki Niemiec.

\section{Zakończenie}

Powstanie Unii Zachodniej było istotnym krokiem w jednoczeniu kontynentu europejskiego, w tym wypadku w zakresie przeciwdziałania zagrożeniu przede wszystkim ze strony Związku Radzieckiego. Był to również niezbędny ruch państw europejskich w celu ostatecznego zakotwiczenia Stanów Zjednoczonych w obronę Europy Zachodniej. Reorientacja polityki Waszyngtonu zapoczątkowana doktryną Trumana, a następnie wyrażana w ramach planu Marshalla i doktryny powstrzymywania została zwieńczona w momencie powstania Sojuszu Atlantyckiego w 1949 r. Już w momencie podpisywania Traktatu Brukselskiego prezydent USA Harry Truman wyraził nadzieję w przemówieniu przed Kongresem, że determinacja wolnych narodów Europy w celu zapewnienia sobie ochrony spotka się z równą determinacją Stanów Zjednoczonych, aby im pomóc (Lord Ismay, 1955). Takie podejście było zgodne z postawą samych Europejczyków. Kilka dni przed podpisaniem Traktatu Brukselskiego brytyjski minister spraw zagranicznych Ernest Bevin wysłał telegram do Waszyngtonu, w którym podkreślał konieczność stworzenia regionalnego Atlantyckiego paktu wojskowego z uwagi na zagrożenie ze strony Związku Radzieckiego (Insall, Salmon, 2015, s. XII). Członkami takiego sojuszu mogłyby być takie państwa, jak Stany Zjednoczone, Wielka Brytania, Kanada, Irlandia, Islandia, Norwegia, Dania, Portugalia, Francja i w przypadku demokratyzacji także Hiszpania.

135 maja 1955 r. Unia Zachodnia została zmieniona w Unię Zachodnioeuropejską na mocy zmodyfikowanego Traktatu Brukselskiego podpisanego w Paryżu 23 października 1954 r. Nowymi członkami UZE stały się Niemcy i Włochy. UZE przestało ostatecznie istnieć 30 czerwca $2011 \mathrm{r}$. w wyniku przejęcia jego funkcji przez Unię Europejską na mocy Traktatu Lizbońskiego. 
Podejście Waszyngtonu i Londynu potwierdzało strategię zapewnienia bezpieczeństwa Europie Zachodniej poprzez pozyskanie wsparcia ze strony Stanów Zjednoczonych dzięki zainicjowaniu współpracy i procesu integracji państw europejskich. Działania Stanów Zjednoczonych i państw Europy Zachodniej wzajemnie się uzupełniały. Dzięki redefinicji polityki Waszyngtonu oraz zaangażowaniu się gospodarczemu i politycznemu USA w sprawy europejskie, Europa Zachodnia mogła się odbudowywać po zniszczeniach wojennych, stabilizować gospodarczo i politycznie oraz przez to zapewnić sobie bezpieczeństwo przed ewentualnym atakiem ze strony Związku Radzieckiego. Współpraca pomiędzy Stanami Zjednoczonymi i Europą Zachodnią miała również wymiar instytucjonalny, czego wyrazem było powstanie 24 sierpnia 1949 r. NATO na mocy podpisanego 4 kwietnia 1949 r. Traktatu Waszyngtońskiego. Nie oznaczało to oczywiście braku problemów pomiędzy stronami, ale niemniej jednak aż do dzisiaj pomimo różnicy zdań i różnorakich wyzwań Sojusz Atlantycki istnieje jako instytucjonalna forma współpracy transatlantyckiej w zakresie bezpieczeństwa.

\section{Bibliografia}

A report to the National Security Council by the Executive Secretary on United States objectives and programs for national security - NSC 68 (1950), Washington, 14.04.1950, http://www.trumanlibrary.org/whistlestop/study_collections/coldwar/documents/pdf/10-1.pdf\#zoom=100, 16.05.2016.

Adamtwaite A. (1986), Britain and the world, 1945-1949: the view from the Foreign Office, w: Power in Europe. Great Britain, France, Italy and Germany in a postwar world, 1945-1950, red. J. Becker, F. Knipping, W. de Gruyter, New York.

Address of the President of the United States delivered before a joint session of the Senate and the House of Representatives, recommending assistance to Greece and Turkey, March 12, 1947 (1947), „80 $80^{\text {th }}$ Congress $1^{\text {st }}$ session. House of Representatives, Document no. 171”, http:// www.trumanlibrary.org/whistlestop/study_collections/doctrine/large/documents/index. php?documentdate=1947-03-12\&documentid=5-9\&pagenumber=1, 14.06.2016.

Arthur Vandenberg: A Featured Biography, http://www.senate.gov/artandhistory/history/common/ generic/Featured_Bio_Vandenberg.htm, 14.06.2016.

Baylis J. (1984), Britain, the Brussels Pact and the continental commitment, „International Affairs”, vol. $60, \mathrm{nr} 4$.

Baylis J. (1993), The diplomacy of pragmatism: Britain and the formation of NATO, 1942-1949, Kent State University Press, Kent, Ohio.

Churchill W. S. (1946), The sinews of peace, Westminster College, Fulton, Missouri, 5.03.1946, http://www.winstonchurchill.org/learn/biography/in-opposition/qiron-curtainq-fultonmissouri-1946/120-the-sinews-of-peace, 15.05.2016.

Churchill W. S. (1994), The tragedy of Europe, w: The European Union. Readings on the theory and practice of European integration, red. B. F. Nelsen, A. C-G. Stubb, Lynne Rienner Publishers, Boulder-London.

Czaputowicz J. (2008), Teorie stosunków międzynarodowych. Krytyka i systematyzacja, Wydawnictwo Naukowe PWN, Warszawa.

Department of State for the press, No. 24, 11.01.1946 (1946), http://www.trumanlibrary.org/whistlestop/study_collections/doctrine/large/documents/pdfs/4 1.pdf\#zoom=100, 17.05.2016.

Einaudi M. (1948), The Italian Elections of 1948, „The Review of Politics”, vol. 10, nr 3. 
Enclosure in No. 3. Views on the international situation expressed by M. Molotov and M. Vyshinsky (2015), w: The Brussels and North Atlantic Treaties, 1947-1949: Documents on British Policy Overseas, Series I, Volume X, red. T. Insall, P. Salmon, Routledge, London.

February 22, 1946. Harry S. Truman Administration File, Elsey Papers (1946), http://www.trumanlibrary.org/whistlestop/study_collections/coldwar/documents/pdf/6-6.pdf, 15.05.2016.

Greenwood S. (1983), Return to Dunkirk: The origins of the Anglo-French treaty of March 1947, „Journal of Strategic Studies”, vol. 6, nr 4.

Insall T., Salmon P. (2015), Preface, w: The Brussels and North Atlantic Treaties, 1947-1949: Documents on British Policy Overseas, Series I, Volume X, red. T. Insall, P. Salmon, Routledge, London.

Jansen M., De Vree J. K. (1985), The ordeal of unity. The politics of European integration 1945-1985, Prime Press, Bilthoven.

Kaplan L. S. (2007), NATO 1948: The Birth of the Transatlantic Alliance, Rowman \& Littlefield Publishers, Lanham.

Kennan and Containment, 1947, http://history.state.gov/milestones/1945-1952/Kennan.

Kissinger H. (1996), Dyplomacja, Philip Wilson, Warszawa.

Kugler R. L. (1990), Laying the foundations: the evolution of NATO in the 1950, RAND Corporation, Santa Monica.

LaFeber W. (1985), America, Russia and the Cold War 1945-1984, Alfred A. Knopf, New York.

Lipgens W. (1982), A history of European integration 1945-1947. The formation of the European unity movement, Clarendon Press, Oxford.

Lord Ismay (1955), NATO, the first five years 1949-1954, North Atlantic Treaty Organization, Paris, http://www.nato.int/archives/1st5years/chapters/1.htm, 1.07.2016.

McVety A. K. (2012), The origins of the Cold War in international perspective, w: A companion to Harry S. Truman, red. D. S. Margolies, Wiley-Blackwell, Oxford.

Meeting notes, ca. February 1947. Subject file, J. M. Jones papers (1947), http://www.trumanlibrary.org/whistlestop/study_collections/doctrine/large/documents/index.php?documentdate $=1947-02-00 \&$ documentid $=8$-4\&pagenumber $=1,20.05 .2016$.

Memorandum by the acting Department of State member (Matthews) to the State-War-Navy Coordinating Committee, Washington, 1.04.1946, w: Foreign relations of the United States, 1946, General; the United Nations, vol. I, U.S. Government Printing Office, 1946 (1946), http:// digicoll.library.wisc.edu/cgi-bin/FRUS/FRUS-idx?type=goto\&id=FRUS.FRUS1946v01\&isi$\mathrm{ze}=\mathrm{M} \&$ submit $=\mathrm{Go}+$ to + page\&page $=1167,15.05 .2016$.

Nye J. S. (2009), Konflikty międzynarodowe. Wprowadzenie do teorii i historii, Wydawnictwa Akademickie i Profesjonalne, Warszawa.

Parzymies S. (1999), Stosunki międzynarodowe w Europie 1945-1999, Wydawnictwo Akademickie DIALOG, Warszawa.

Ramsden J. (1999), One - Mr. Churchill Goes to Fulton, w: Churchill's ,Iron Curtain” Speech Fifty Years Later, red. J. W. Muller, University of Missouri Press, Columbia-London.

Rupp R. E. (2006), NATO after 9/11. An Alliance in continuing decline, Palgrave Macmillan, New York.

Scott L. (2008), Historia stosunków międzynarodowych w latach 1945-1990, w: Globalizacja polityki światowej. Wprowadzenie do stosunków międzynarodowych, red. J. Baylis, S. Smith, Wydawnictwo Uniwersytetu Jagiellońskiego, Kraków.

Shlaim A. (1983), The United States and the Berlin Blockade 1948-1949. A Study in Crisis DecisionMaking, University of California Press, Berkeley-Los Angeles-London.

Sloan S. R. (2010), Permanent Alliance? NATO and the Transatlantic Bargain from Truman to Oba$m a$, Continuum, New York. 
Speech by George C. Marshall, „European Initiative Essential to Economic Recovery”, June 5, 1947 (1947), „The Department of State Bulletin”, vol. XVI, nr 415, http://www.trumanlibrary.org/ whistlestop/study_collections/marshall/large/documents/index.php?pagenumber=2\&documentdate=1947-06-05\&documentid=8-7, 18.06.2016.

Stalin J. (1954), Speeches delivered at meetings of voters of the Stalin electoral district, Moscow, December 11, 1937 and February 9, 1946, Foreign Languages Publishing House, Moscow.

Sutton M. (2007), France and the construction of Europe, 1944-2007. The geopolitical imperative, Berghahn Books, New York.

Telegram, George Kennan to George Marshall [,Long Telegram”], February 22, 1946. Harry S. Truman Administration File, Elsey Papers (1946), http://www.trumanlibrary.org/whistlestop/study_collections/coldwar/documents/pdf/6-6.pdf, 15.05.2016.

Treaty of Alliance and Mutual Assistance between the United Kingdom and France (Dunkirk, 4 March 1947), Treaty Series. Treaties and international agreements registered or filed and recorded with the Secretariat of the United Nations. 1947. New York: United Nations (1947), http:// www.cvce.eu/viewer/-/content/1 fb9f4b5-64e2-4337-bc78-db7e1978de09/en, 1.04.2016.

Treaty of Economic, Social and Cultural Collaboration and Collective Self-Defence. 17 March 1948 (2009), http://www.nato.int/cps/en/natohq/official_texts_17072.htm, 16.06.2016.

Truman's inaugural address, January 20, 1949 (1949), http://www.trumanlibrary.org/whistlestop/50yr_archive/inagural20jan1949.htm, 25.05.2016.

United Nations. 1947. New York: United Nations (1947), http://www.cvce.eu/viewer/-/content/1fb9f4b5-64e2-4337-bc78-db7e1978de09/en, 23.06.2016.

Urwin D. W. (1995), The Community of Europe. A history of European integration since 1945, Longman, London.

X (Kennan G. F.) (1987), The sources of Soviet conduct, „Foreign Affairs”, vol. 65, nr 4.

\section{Streszczenie}

Celem artykułu jest ukazanie przyczyn zainicjowania i rozwoju transatlantyckich stosunków bezpieczeństwa w latach 1945-1948. Szczególny nacisk jest położony na ukazanie związku pomiędzy wstępnymi działaniami państw Europy Zachodniej na rzecz osiaggnięcia jedności europejskiej a redefinicją polityki zagranicznej Stanów Zjednoczonych tuż po zakończeniu drugiej wojny światowej. Aktywność państw Europy Zachodniej oraz Stanów Zjednoczonych podyktowana była zagrożeniem ze strony Związku Radzieckiego, co skutkowało wybuchem zimnej wojny. Główni gracze w Europie Zachodniej, tj. Wielka Brytania i Francja, dążyły do zapewnienia bezpieczeństwa, początkowo biorąc pod uwagę ewentualny powrót Niemiec do agresywnej polityki, ale szybko zaczęto przede wszystkim brać pod uwagę możliwość ekspansji komunizmu. W artykule poddane są analizie dwie istotne inicjatywy europejskie, tj. Traktat z Dunkierki (1947 r.) oraz ustanowienie Unii Zachodniej na mocy Traktatu Brukselskiego (1948 r.). Powstanie Unii Zachodniej jako europejskiego sojuszu wojskowego wpłynęło na decyzję Stanów Zjednoczonych o powołaniu w 1949 r. Sojuszu Atlantyckiego. Powstanie NATO było zwieńczeniem redefinicji polityki USA wobec Europy po 1945 r. Amerykanie odeszli od tradycyjnej polityki izolacjonizmu na rzecz zaangażowania w sprawy europejskie w celu wspomożenia w odbudowie gospodarczej państw Europy Zachodniej, aby mogły się one stabilizować gospodarczo i politycznie (plan Marshalla) i nie wpadły w strefę wpływów Związku Radzieckiego (doktryna powstrzymywania). W artykule występują odwołania do wiodących teorii stosunków międzynarodowych, tj. realizmu i liberalizmu.

Słowa kluczowe: transatlantyckie stosunki bezpieczeństwa, redefinicja polityki zagranicznej USA po 1945 r., integracja europejska, polityka zagraniczna Wielkiej Brytanii i Francji, teorie realistyczna i liberalna 


\title{
European integration and the redefinition of US foreign policy: the causes for the initiation and development of transatlantic security relations 1945-1948
}

\begin{abstract}
Summary
The aim of the article is to show reasons to initiate and to develop transatlantic security relations from 1945 till 1948. A particular emphasis is put on showing the relationship between the initial activities of Western European countries to achieve European unity and the redefinition of US foreign policy after the Second World War. Activities of Western European countries and the United States were dictated by the threat from the Soviet Union, which resulted in the outbreak of the Cold War. Key players in Western Europe, like Great Britain and France, sought to ensure their security, initially considering a possible return of Germany to an aggressive policy, but quickly began primarily to take into account the possibility of the expansion of communism. Two important European initiatives, i.e. the Treaty of Dunkirk (1947) and the establishment of the Western Union by the Treaty of Brussels (1948) are analyzed in the article. The establishment of the Western Union as a European military alliance influenced the US decision to create the Atlantic Alliance in 1949. The establishment of NATO was the culmination of a redefinition of US policy towards Europe after 1945. Americans departed thus from their traditional isolationist policy in favour of engagement in European affairs to assist in the economic reconstruction of Western European countries, so they could stabilize economically and politically (the Marshall Plan) and did not fall into the sphere of influence of the Soviet Union (the doctrine of containment). The article refers to the leading theories of international relations, i.e. realism and liberalism.
\end{abstract}

Key words: transatlantic security relations, redefinition of foreign policy of the United States after 1945, European integration, foreign policy of Great Britain and France, theories of realism and liberalism 